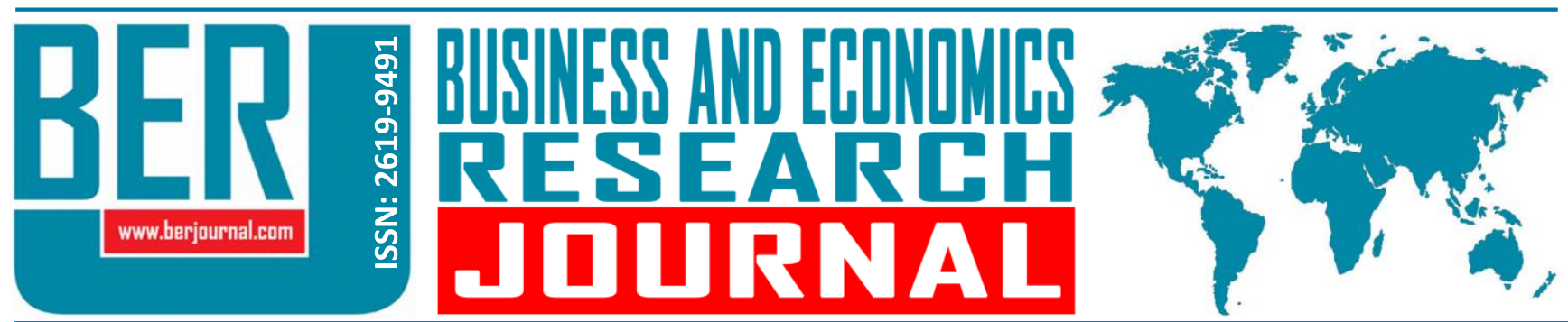

Business and Economics Research Journal Vol. 11, No. 1, 2020, pp. 279-291 doi: 10.20409/berj.2020.250

\section{Fonksiyonel Gıdalara Yönelik Güvenin Satın Alma İsteği Üzerindeki Etkisi: Genel Sağlık İlgileniminin Düzenleyici Rolü}

\author{
Yusuf Arslan ${ }^{\mathrm{a}}$
}

Öz: Tüm dünyada ve özellikle de Avrupa'da fonksiyonel gıda pazarı günden güne büyümektedir. Türkiye'deki fonksiyonel gıda pazarı, henüz yeterince gelişmemiş olmakla birlikte, tüm dünyada en hızlı büyüyen pazarlardan bir tanesi olarak göze çarpmaktadır. Ancak literatür incelendiğinde, fonksiyonel gıdalara yönelik pazar mekanizmalarının tüketici perspektifinden yeterince ele alınmadığı ve anlaşılmadığı görülmektedir. Bu bağlamda bu çalışma tüketici perspektifine bir katkı sağlamak amacıyla, tüketicilerin fonksiyonel gıda tercihlerini belirleyen önemli öncüllerden olan güven ve tüketici ilgilenimine odaklanmıştır. Bu odak çerçevesinde fonksiyonel gıdalara yönelik güveninin, bu ürünleri satın alma isteğini etkileyip etkilemediği ve bu ilişkide tüketici sağlık ilgileniminin rolünün olup olmadığının anlaşılması amaçlanmıştır. Bu amaca ulaşmak için oluşturulan bir anket vasıtasıyla 373 tüketiciden toplanan verilerle araştırma hipotezleri test edilmiştir. Elde edilen bulgulara göre, tüketici güveni ile tüketicilerin fonksiyonel gıdaları satın alma isteği arasında pozitif bir ilişki olduğu ve tüketicinin sağlık ilgileniminin bu ilişki üzerinde düzenleyici bir etkiye sahip olduğu sonucuna ulaşılmıştır. Elde edilen bu sonuçlar, özellikle gıda sektörü oyuncularının faydalanabileceği nitelikte bilgiler ortaya koyarken, fonksiyonel gıda tüketiminin tüketici temelli öncüllerinin anlaşılması bağlamında da pazarlama literatüre katkı sağlamaktadır.

\section{The Effect of Trust in Functional Foods on Willingness to Buy: The Moderating Role of General Health Interest}

\begin{abstract}
The functional food market is growing day by day all over the world and especially in Europe. The market in Turkey has not yet been sufficiently developed, stands out as one of the fastest-growing markets in the world. However, when the literature is examined, it is seen that market mechanisms for functional foods are not adequately addressed and understood from the consumer perspective. In this context, this study focuses on the antecedents determining the consumers' willingness to buy of functional foods in order to provide insight from the consumer perspective. In this context, in order to contribute to the consumer perspective, this study focuses on consumer trust and interest, which are important antecedents determining the functional food preferences of consumers. Within this focus, it is aimed to understand whether trust in functional foods affects the decisions of purchasing these products and whether consumer health interest plays a role in this relationship. The research hypotheses were tested with data collected from 373 consumers by means of a questionnaire created to achieve this aim. According to the findings, it is concluded that there is a positive relationship between consumer trust and willingness to buy functional foods, and consumer health interest has a moderator effect on this relationship. These results provide information that can be benefited especially by food sector players, while contributing to marketing literature in the context of understanding consumer-based antecedents of functional food consumption.
\end{abstract}

\section{Anahtar Sözcükler:}

Fonksiyonel Gıda, Tüketic Güveni, Sağlık ilgilenimi, Düzenleyici Etki, Satın Alma İsteği

JEL: M10, M31

$\begin{array}{ll}\text { Geliş } & : \text { 22 Ekim } 2019 \\ \text { Düzeltme } & : 09 \text { Kasım } 2019 \\ \text { Kabul } & : \text { 30 Aralık 2019 } \\ \text { Tür } & \text { : Araştırma }\end{array}$

Keywords: Functional Foods, Consumer Trust, Health Interest, Moderating Effect, Willingness To Buy

JEL: M10, M31

Received : 22 October 2019

Revised : 09 November 2019

Accepted : 30 December 2019

Type : Research 


\section{Giriş}

2012 yılında dünyadaki toplam ölümlerin yaklaşık \% 68'inde rol oynadığı bildirilen kronik hastalıklar, tüketici sağlığını giderek artan bir biçimde tehdit etmektedir. Bu oran Türkiye gibi gelişmekte olan ülkeler için \%86 gibi çok daha yüksek seviyelerde gerçekleşmektedir (WHO, 2014). Kronik hastalıklardaki artışın temel nedeni olarak, tüm dünya devletlerinin üstesinden gelmek için yoğun bir şekilde mücadele ettiği yanlış ve zararlı bireysel diyetler ve yaşam tarzı görülmektedir (WHO, 2003). Bununla birlikte, sağlıklı besinlerden oluşan bir diyet ve sağlıklı bir yaşam tarzının, kronik hastalıkların önlenmesinde en önemli faktörlerden olduğu kanıtlanmıştır (CDC, 2019). Son yıllarda tüketicilerin artan bilinciyle birlikte sağılıkı gıdaya olan talepteki artışta bu unsurların etkili olduğu söylenebilir.

20. yüzyılın başlarında beslenme biliminin ana odağı, bireylerin vücut gelişimini desteklemek gibi basit unsurlardan oluşmaktayken (Arai, 2002), günümüzde değişen yaşam biçimleriyle paralel olarak beslenme tercih ve biçimleri açısından adeta paradigmal bir değişim yaşanmaktadır. Bireyler artık daha az çalışmakta, boş geçirdikleri zaman artmakta ve bu da kalori ve enerji harcamalarını görece olarak azaltmaktadır (Popkin, 1999). Bununla birlikte, sağlıklı bir yaşam için aşırı miktarda enerji alımı ve bunlarla ilişkili hastalıklardan kaçınmak gerekirken, gerekli besinlerin yeterli bir şekilde alımını sağlamak için yeterli nicelik ve niteliğe sahip gıdalar tüketmeye hala ihtiyaç vardır (Howlett, 2008). Bu durum, içerdiği kalori ve enerji değerleri bakımından düşük ancak yine de besin değeri açısından temel ve gerekli bileşenleri içeren gıda ürünlerine yönelik bir talep yaratmıştır. Ortaya çıkan bu pazar fırsatı gıda sektörü oyuncuları tarafından değerlendirilmiş ve yeni bir gıda türü olarak fonksiyonel gıdalar pazara sürülmüştür. Fonksiyonel gıda terimi ilk olarak 1980'lerde Japonya pazarında kullanılmıştır. Fonksiyonel gıdalar, besleyici olmanın yanı sıra insan sağlığına yönelik ekstra faydaları olan bileşenler içeren gıda ürünleri olarak tanımlanabilir (Hutt, 2016). Fonksiyonel gıdalar temelde iki gruba ayrılır. İlk grubu, kendi doğal yapısında belirli ölçüde fonksiyonel bileşen içeren domates, yeşil çay ve yulaf gibi gıda ürünleri oluşturmaktadır. Diğer grubu ise, belirli bir bileşenin içeriğine dahil edilmesi veya belirli bir bileşenin içeriğinden çıkarılması ile fonksiyonel olma özelliği kazanan probiyotik yoğurt, omega-3 içeren yumurta ve iyotlu tuz gibi gıda ürünleri oluşturmaktadır (Remarcle, 2004). Birinci gruba giren ürünler çoğunlukla doğal ürünlerken, ikinci gruba giren ürünler ise belirli bir tasarım sonucu üretilen ürünlerdir. Bu çalışma, özellikle de geniş ürün yelpazesi ve daha büyük pazar potansiyeli dikkate alınarak, ikinci grubu oluşturan işlenmiş fonksiyonel gıdalara odaklanmaktadır.

İşlenmiş ürünlerden oluşan fonksiyonel gıda pazarı birçok ülkede sürekli olarak büyümektedir. 20032008 yılları arasında fonksiyonel gıda pazarı parasal değer açısından tüm dünyada ortalama olarak \%40'ık bir büyüme göstermiş̧ir (Dutra de Barcellos ve Lionello, 2011). Euromonitor tarafından gerçekleştirilen çalışmaya göre fonksiyonel gıda pazarının 2017 yılı küresel değeri 38 milyar \$'dır (Cambridge Commodities, 2017). Fonksiyonel gıdaların anavatanı olan Japonya pazar büyüklüğü açısından da liderdir. Japonya'yı takiben $A B D$ ve $A B$ gelmektedir (Bleiel, 2010). Türkiye ise, fonksiyonel gıda ürünlerinin pazar penetrasyonu bakımından öncü ülkelere kıyasla oldukça geridedir. Ancak bu geri kalmışıı, Türkiye'nin oldukça hızlı büyüyen bir pazar olduğu gerçeğini değiştirmemektedir. Güncel Euromonitor verilerine göre Türkiye, 2012-2017 yılları arasında fonksiyonel gıda satışları hacminde \%52'lik artışla 303 milyon \$'dan, 461 milyon \$'a ulaşarak, tüm dünya pazarları içerisinde en yüksek büyüme oranlarını yakalayan ülke olmuştur. Aynı dönemde, pazarın gelişmiş ekonomileri Fransa (-\%12), i̇talya (-\%8) ve Almanya (-\%3) gibi ülkelerde fonksiyonel gıda satışlarında azalmalar görülmüştür (Euromonitor International, 2017). Bu durum, Türkiye pazarındaki fonksiyonel gıda ürünlerinin başarısını, uluslararası pazar dinamikleri açısından, görece daha önemli bir hale getirmektedir. Zira Türkiye, 82 milyon nüfusu ve fonksiyonel gıda pazarında son dönemde elde ettiği yüksek büyüme seviyeleri ile 2020 yılında 192 milyar \$ olacağı tahmin edilen fonksiyonel gıda pazarı pastasından daha büyük bir pay alma potansiyeline sahip bir ekonomi olarak görülmektedir (Kaur ve Singh, 2017). Türkiye fonksiyonel gıda pazarındaki yüksek büyüme oranlarına rağmen, gerçekleştirilen akademik çalışmaların sonuçlarına göre tüketicilerin bu gıdalara yönelik farkındalık ve bilgi düzeylerinin oldukça düşük olduğu görülmektedir (örneğin; Hacıoğlu ve Kurt, 2012; Büyükkaragöz vd., 2014). Türkiye fonksiyonel gıda pazarındaki önemli potansiyelden faydalanabilmek için, tüketicilerin fonksiyonel gıda tercihinin belirleyicilerinin tüm detaylarıyla anlaşılması gerektiği söylenebilir. Yabancı literatürdeki çalışmalar Türkiye pazarı özelindeki dinamikleri anlamada yeterli olmayabilir. Zira fonksiyonel gıdaların kabulünü etkileyen unsurlar kültürden kültüre farklıık 
göstermektedir. Örneğin; Dolgopolova vd. (2015) tarafından gerçekleştirilmiş olan çalışmaya göre Alman ve Rus tüketicilerin fonksiyonel gıda ürünlerini kabulünü etkileyen faktörler birbirinden farklıdır. Bu bağlamda, bu çalışmanın temel amacı, Türk tüketicilerin fonksiyonel gıda tercihlerinin ve buna etkide bulunan unsurların anlaşılmasına katkı sunmaktır. Çalışma bu amaca ulaşmak için fonksiyonel gıdaları spesifik olarak Türkiye perspektifinden ele almaktadır. Çalışma, fonksiyonel gıda tercihlerinde önemli bir öncül olarak tüketici güvenini ortaya koyarken, tüketici sağlık ilgileniminin bu ilişkideki rolünü incelemektedir.

\section{Kavramsal Çerçeve}

\subsection{Tüketici Güveni}

Güven, teorik bir perspektiften değerlendirildiğinde, bireylerin zihnindeki karmaşıklığın azaltılması ve risklerle başa çıkmanın bir aracı olarak hizmet etmektedir (Luhmann, 2000). Güvenin tüketicilerin pazarda karşılaştıkları ürünlere yönelik algıladıkları riski azaltıcı, memnuniyet ve sadakati artırııı rolü, tüketicilerin bu ürünlere karşı davranışlarında önemli bir belirleyici olmasını sağlar (Fandos Herrera ve Falavian Blanco, 2011). İçinde bulunduğumuz dönemde güven kavramı özellikle de gıda konusunda önemini giderek artırmaktadır. Tüketiciler etiketlerinde yazan bilgilerin doğruluğuna güvenebilecekleri sağlıklı gıdalar tüketmek istemekle birlikte, hangi gıda ürünlerinin gerçekten sağlıklı olduğu konusunda kafaları oldukça karışıtıtır ve gıda sektörü oyuncularına yönelik bir güven eksikliği mevcuttur (Arslan, 2019). Bu durum, yapısal bir sorun olarak değerlendirilebilir. Çünkü günümüz modern toplumlarında birçok birey tükettikleri gıda ürünlerini kendileri üretmek yerine bir perakendeciden satın almaktadır. Bu ürünlerin üretim sürecine bizzat şahit olunması imkanı olmadığı için, bu ürünlerin iddia edilen niteliklere sahip olup olmadığı tüketiciler için her durumda bir belirsizlik içerir. Bu bakımdan bireyler genellikle üreticisine güvendikleri gıda ürünlerini tercih etme eğilimindedir (Brom, 2000). Pazara nispi olarak yeni sürülmüş olmaları ve üretimindeki teknik bilgi gereksinimi nedeniyle, bu durumun fonksiyonel gıda ürünleri için de "en az" diğer gıda ürünleri için olduğu kadar geçerli olması beklenebilir.

Kompleks bir yapısı olan güven kavramı, özellikle tüketicilerin risk altında karar verme süreçlerinde etkili bir unsurdur (Glaeser vd., 2000). Daha öncede bahsedildiği gibi özellikle de Türkiye pazarındaki tüketicilerin fonksiyonel gıdalara yönelik düşük bilinç ve farkındalık düzeyleri nedeniyle bu ürünlere yönelik algılanan riskin yüksek olması beklenebilir bir durumdur. Bu perspektiften, Türkiye'de fonksiyonel gıda pazarının dinamiklerini anlamada tüketici güveni önemli bir unsur olarak nitelendirilebilir.

Tüketici güveni kavramı literatürde ayrıca tüketicinin gıda satın alma kararlarına etkisi bakımından önemli bir faktör olarak ekle alınmıştır (Hobbs ve Goddard, 2015; Huang vd., 2019). Ancak, tüketici güveninin geniş bir kavram olması ve farklı yönleri bulunması sebebiyle, satın alma davranışları üzerindeki etkisinin değişkenlik gösterdiği gözlemlenmektedir. Örneğin bu durumu gıda tercihleri üzerinden ele alan çalışmalar incelendiğinde, düzenleyici ya da kanun koyuculara yönelik güven (Frewer vd., 2003) ve gıda sektörüne yönelik güven (Siegrist vd., 2008) kavramlarının fonksiyonel gıda ürünleri satın alma tercihleri üzerinde ayrı ayrı etkili olduğu görülmektedir. Bu mantık çerçevesinde, güven kavramının doğası gereği farklı yönleriyle incelenebileceği düşünüldüğünde, gerçekleştirilecek her farklı çalışmada incelendiği bağlama göre ele alınmasının yerinde olacağı söylenebilir. Bu nedenle, bu çalışmada güven, tüketicilerin spesifik olarak fonksiyonel gıda ürünlerine yönelik hissettikleri güvenleri bağlamında ele alınmaktadır.

\subsection{Tüketici Genel Sağlık ilgilenimi}

Sağlık bilinci, bireylerin sağlıklı eylemlerde bulunmaya hazır olma derecesi olarak tanımlanabilir (Schifferstein ve Oude Ophuis, 1998). Sağlık bilincinin oldukça geniş bir kavram olduğu düşünülerek çalışma kapsamında, tüketici-sağlık ilişkisi meselesini daha dar bir perspektiften ele alan ve gıda ile ilgili davranışlara odaklanan "genel sağlık ilgilenimi" kavramı irdelenmektedir. Genel sağlık ilgilenimi, tüketicilerin sağlıkı beslenmeye yönelik ilgilenimini ifade etmektedir (Roininen vd., 1999).

Sağlıklı beslenme bağlamında, tüketicilerin hangi gıda ürünlerinin gerçekten de sağ|ıklı olduğunu bilebilmesi önemli bir meseledir. 21. yüzyııın başlarından itibaren gıda sektöründe faaliyet gösteren çoğu firma, tüketicilerdeki artan sağlık bilincine paralel olarak, satışa sundukları ürünlerin ambalajında sağlığı 
koruyucu ve geliştirici etkilerini vurgulamaya başlamıştır (Heasman ve Mellentin, 2001). Tüketicilerin güven ve ilgilenim düzeyleri tartışılır olmakla birlikte, işte bu gıda ambalajlarına yazılan bilgiler tüketicilere hangi ürünün hangi bileşenleri içerdiği ve daha sağlıklı olduğu sorularını cevaplamalarında yol gösterici niteliktedir (Williams, 2005). Bununla birlikte, günümüzde bir gıda ürününün ambalajında ürünün spesifik bir faydasından bahsetmek 2000'li yıllardan önceki dönem kadar kolay değildir. Özellikle de 2006 yılından itibaren AB tarafından gerçekleştirilen düzenlemelerle, bu iddialarda bulunabilmek belirli şartlara bağlanmıştır. Örneğin gerekli özellikleri sağlamayan ve gerekli denetimlerden geçmemiş bir gıda ürününün ambalajına "organik" yazılarak pazara sunulması yasaktır (EPCE, 2006). Bu bakımdan "fonksiyonel" özelliği olan gıdalar, sağıkı beslenmeye özen gösteren tüketicilerin sağlıklı gıda temini arayışlarında, işlerini kolaylaştırıcı nitelikte olan önemli alternatifler olarak değerlendirilebilir ${ }^{1}$. Zira tüketiciler örneğin omega-3 açısından zenginleştirilmiş bir yumurta satın aldıklarında bu ürünün gerçekten de ilgili bileşeni içerip içermediğine yönelik bilgiyi yalnızca satıcının beyanından değil, ürünün ambalajı ve markasından da anlayabilecektir.

\section{Araştırma Hipotezlerinin Geliştirilmesi}

\subsection{Fonksiyonel Gıdalara Yönelik Tüketici Güveni ve Tüketici Satın Alma İsteği}

Tüketici güveni, fonksiyonel gıdalara yönelik tüketici tutum ve davranışlarının oluşmasında, özellikle de tüketicilerde bu ürünlerin niteliği ve insan sağlığı üzerindeki potansiyel etkilerine yönelik bilgi eksikliği olması bakımından önemli bir kavram olarak ele alınmaktadır (Barrios vd., 2008). Gıda ürünlerinin insan sağlığını etkileme potansiyeli yüksek olduğu için, tüketicilerin özellikle de pazarda nispi olarak kısa süredir var olan yeni tür ürünlere yönelik genel olarak şüpheci ve çekingen bir tavır sergilemeleri normal olarak karşılanabilir. Tüketicilerin, güven eksikliğinin bir sonucu olarak ortaya çıkan ve gıda-fobisi olarak adlandırılan, gıdalardaki yeniliklerle ilgili göreceli muhafazakârlı̆̆ı da göz önüne alındığında, fonksiyonel gıdalar için durum daha kötü olabilir (Urala ve Lahteenmaki, 2004; Dolgopolova vd., 2015). Buna ek olarak, Türkiye pazarındaki tüketicilerin fonksiyonel gıda ürünlerine yönelik düşük farkındalık düzeyleri de hesaba katıldı̆ıında (Büyükkaragöz, 2014), bu pazarda fonksiyonel gıda ürünü tercihlerinde güvenin öneminin daha fazla olması da beklenebilir. Bu çerçevede aşağıdaki hipotez geliştirilmiş̧ir;

H1: Tüketicilerin fonksiyonel gıdalara yönelik güveni, bu ürünlere yönelik satın alma isteğini olumlu olarak etkiler.

\subsection{Tüketici Sağlık ilgilenimi ve Fonksiyonel Gıdalara Yönelik Satın Alma İsteği}

Sağlık ilgilenimi yüksek olan bireylerin, günlük diyetleri için sağlıklı gıda ürünlerini tercih etmeleri öngörülebilir bir durumdur. Bu konuda gerçekleştirilen önceki araştırmalar, sağlıklı beslenmeyi bir tutum olarak benimsemiş insanların iyi oluşları hakkında daha fazla endişe duyduklarını, sağlıklarını ve yaşam kalitelerini korumak ve geliştirmek için motive olduklarını göstermektedir (Hieke ve Grunet, 2018). Tüketiciler bu amaçlara ulaşmak için organik gıdalar gibi sağlıklı algıladıkları ürünleri tüketme eğilimindedir (Lockie vd., 2002). Bu durumun benzer şekilde fonksiyonel gıda tüketimi için de geçerli olması beklenebilir. Çünkü daha sağlıklı bir yaşam tarzı ve yeme alışkanlığı olan tüketiciler, fonksiyonel gıdalara karşı daha olumlu bir tutum sergilemeye ve onları kullanma konusunda daha istekli olma eğilimindedir (Chen, 2011a, 2011b). Bu mantık çerçevesinde ve tüketicilerin genel sağlık ilgilenimi ve fonksiyonel gıda tercihleri arasında gerçekleşmesi beklenen pozitif ilişki bağlamında aşağıdaki hipotez geliştirilmiştir;

H2: Tüketicilerin genel sağlık ilgilenim düzeyi fonksiyonel gıda satın alma isteğini olumlu yönde etkilemektedir.

\subsection{Tüketici Güveninin Fonksiyonel Gıda Satın Alma İsteğine Etkisinde Genel Sağlık İlgileniminin} Düzenleyici Rolü

Tüketici ürünlerine yönelik güvensizlik, bu ürünlerin tercihinde önemli bir etmen olarak öne sürülmüştür (Frewer vd., 2003; Siegrist vd., 2008). Yani tüketicilerin herhangi bir ürüne yönelik güvenleri düşükse bu ürünü tercih etme ihtimalleri de o ölçüde düşecektir. Yukarıdaki açıklamalar ışı̆̆ında fonksiyonel gıdalar için de durumun benzer olduğu vurgulanmıştır. Ancak tüketicilerin fonksiyonel gıda ürünlerine 
güvenmesi, bu ürünleri tercih etmelerinde tek başına yeterli olmayabilir. Söz konusu ilişkiye farklı unsurların dahil edilmesi ilişkinin yönünü ve şiddetini değiştirebilir. Bu çalışmada potansiyel düzenleyici değişkenlerden bir tanesi olarak tüketicilerin sağlık ilgilenim düzeyi ele alınmıştır. Zira fonksiyonel gıda tercihlerinde tüketici sağlık ilgilenimi önemli bir öncül olarak ortaya konmuştur. Bu çerçevede, sağlıklı bir yaşam tarzına yönelik tüketici tutumları, sağlıklı gıda ürünlerinin tercihinde de önemli bir konudur. Literatürde, sağlıklarını korumaya daha yatkın olan tüketicilerin, diğer tüketici gruplarından daha fazla fonksiyonel gıda ürünü satın aldıkları da yaygın olarak kabul edilmektedir. Ayrıca sağlıkla ilgili tutumlar, fonksiyonel gıdaların kabulü (Verbeke, 2006) ve tüketici tercihleri (Chen, 2011a) bakımından geçerli bir öncül olarak kabul edilmektedir. Bu bağlamda, bir tüketici fonksiyonel gıdalara yönelik güven duyabilir, ancak tüketicinin genel sağlık ilgileniminin düşük olması durumunda satın alma gerçekleşmeyebilir. Benzer şekilde, fonksiyonel gıdalara yönelik güveni yüksek olan bir tüketicinin, sağlık ilgilenim düzeyinin de yüksek bir düzeyde olmasının, bu gıdaları satın alma isteğini olumlu ölçüde etkilemesi beklenebilir. Bu çerçevede aşağıdaki hipotez geliştirilmiştir;

H3: Tüketicilerin genel sağlık ilgilenimi, fonksiyonel gıdalara yönelik güven ve bu ürünlere yönelik satın alma isteği arasındaki iliş̧i üzerinde düzenleyici bir etkiye sahiptir. Bu etki, tüketicilerin genel sağlık ilgilenimi arttıkça, tüketici güveni ve satın alma isteği arasındaki ilişkinin pozitif yönlü etkileneceği şekilde gerçekleşecektir.

Araştırma modeli Şekil 1'de gösterilmektedir.

Şekil 1. Araştırma Modeli

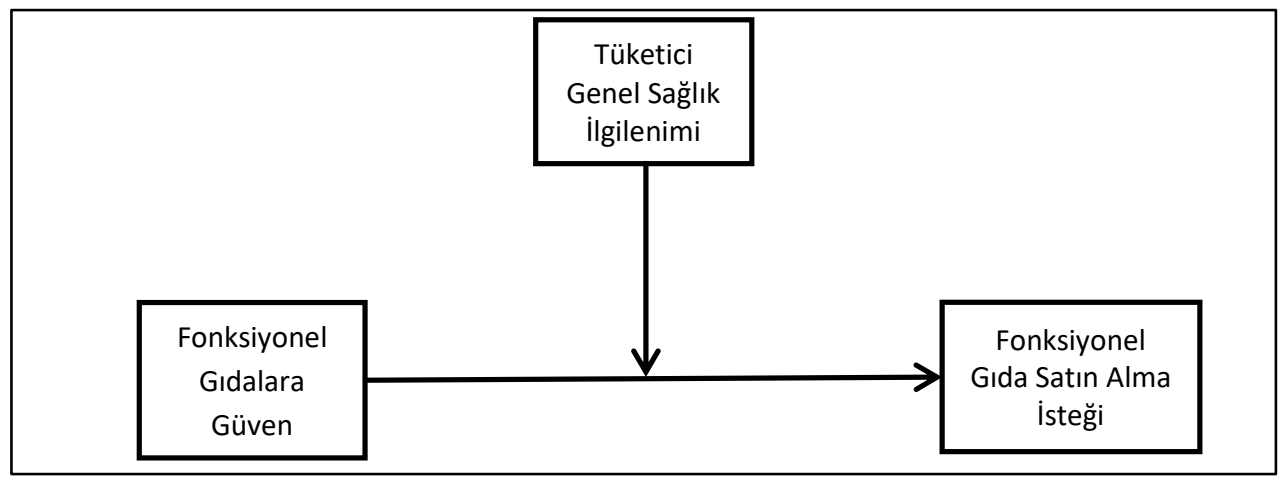

\section{Metodoloji}

\subsection{Araştırma Dizaynı}

Araştırmanın evrenini Sakarya ilinde ikamet eden 18 yaş üzeri tüketiciler oluşturmaktadır. Araştırma evrenini oluşturan tüm bireylere ulaşma imkanı olmadığından örnekleme yöntemine başvurulmuştur. Sakarya ilindeki 18 yaş üzeri tüm bireyleri içeren bir örneklem çerçevesi temin etmenin ve tesadüfi örnekleme yöntemi kullanmanın çalışmanın imkanları dahilinde mümkün olmaması nedeniyle çalışmada kolayda örnekleme yöntemi kullanılmıştır. TÜik 2018 yılı verilerine göre Sakarya'nın 2018 yılı sonu itibariyle nüfusu 1.010.700'dür (TÜiK, 2019). Bu büyüklükte bir evren için gereken örneklem büyüklüğü istatistiki bir yaklaşıma göre 384 kişidir (Sekeran, 2016). Araştırmanın imkanları çerçevesinde, 2018 Eylül ve Ekim ayları süresinde kendilerine önceden eğitim verilmiş anketörler vasıtasıyla ve kolayda örnekleme yöntemi benimsenerek 412 adet anket elde edilmiştir. Eksik ve hatalı doldurulmuş olan anketler elendikten sonra geriye 373 adet nitelikli anket kalmış ve 384 sayısına ulaşılamamıştır. Ancak literatürde benimsenen diğer bir yaklaşıma göre, ölçekte kullanılan ifade sayısının 10 katı kadar örnek hacmi gerekli analizlerin gerçekleştirilebilmesi için yeterli görülmektedir (Coşkun vd., 2017). Elde edilen geçerli 373 anketin 384 sayısına yakınlığı ve ankette kullanılan ifade sayısının (13 ifade) on katından oldukça fazla olması değerlendirilerek araştırmanın analizleri elde edilen bu verilerle gerçekleştirilmiştir. 
Literatürde fonksiyonel gıdaların genel ve net bir tanımı olmaması nedeniyle her katılımcının bu terimden çıkaracağı anlamın farklı olabileceği düşünülmüş ve bir anlam karmaşasına mahal vermemek amacıyla anketin giriş kısmında, araştırma perspektifinden fonksiyonel gıdaların kısa ve net bir tanımı verilerek, bu gıdaların piyasada bulunan örneklerinden bahsedilmiştir. Bu yolla katılımcıların araştırma anketini cevaplarken zihinsel olarak benzer bir düzlemde olması amaçlanmıştır.

\subsection{Araştırmada Kullanılan Ölçekler}

$\mathrm{Bu}$ araştırmada kullanılan ölçekler, ilgili kavramları ölçme becerisi literatürde daha önceden kanıtlanmış, geçerli ve güvenilir ölçeklerdir. Fonksiyonel gıdalara yönelik güvenin ölçülmesinde Urala ve Lahteenmaki'nin (2007) geliştirmiş olduğu ölçek kullanılmıştır. Ölçek 5 maddeden oluşmakta olup 5'li Likert formundadır (1-Kesinlikle katılmıyorum, 5-Kesinlikle katılıyorum). Genel sağlık ilgilenim düzeyinin ölçülmesinde Roininen vd. (1999) tarafından geliştirilen ölçek kullanılmıştır. Ölçek 5'li Likert formundadır ve 8 maddeden oluşmaktadır. Fonksiyonel gıdalara yönelik satın alma isteği ise Siegrist vd.'nin (2008) çalışmasından uyarlanmış olan 5 seçenekli bir soru ile ölçülmüştür (Fonksiyonel gıdaları satın alma isteğim; 1Çok düşük ,...., 5-Çok yüksek). Araştırmada kullanılan ölçeklerin orijinal dili İngilizce olduğu için, ölçeklerin aynı anlamı tam olarak ihtiva edebilmesi ve çevirilerin düzgün bir şekilde gerçekleştirilebilmesi adına uzman görüşüne başvurulmuştur. Bu çerçevede alanda uzman ve yeterli ingilizce dil bilgisine sahip 3 akademisyene danışılarak "çeviri-geri çeviri yöntemi" uygulanmıştır (Brislin, 1970). Ayrıca, anketin içsel tutarııı̆ını maksimize etmek amacıyla bazı sorular kasten ters kodlanmıştır. Kullanılan ifadeler Tablo 2'de verilmiştir.

\section{Analiz ve Bulgular}

Çok kutupluluktan kaçınmak için, araştırma modelindeki sürekli değişkenlerin moderatör analizinde kullanılmadan önce ortalamalarını alınması önerilmektedir (Aiken ve West, 1991). Bu perspektifi takiben, analizler gerçekleştirmeden önce bağımsız değişken, bağımlı değişken ve düzenleyici değişkenin ortalamaları alındıktan sonra analiz aşamasına geçilmiştir. Araştırma modelinin testi ve demografik bilgilerin elde edilebilmesi için gerçekleştirilen analizlerde SPSS 21 programı kullanılmıştır. Ayrıca araştırmanın geçerlilik ve güvenilirlik analizleri kapsamında gerçekleştirilen doğrulayıcı faktör analizi için AMOS 21 programı kullanılmıştır. Araştırma modelinin istatistiki gösterimi Şekil 2'de verilmiştir.

Şekil 2: Araştırma Modelinin İstatistiki Gösterimi

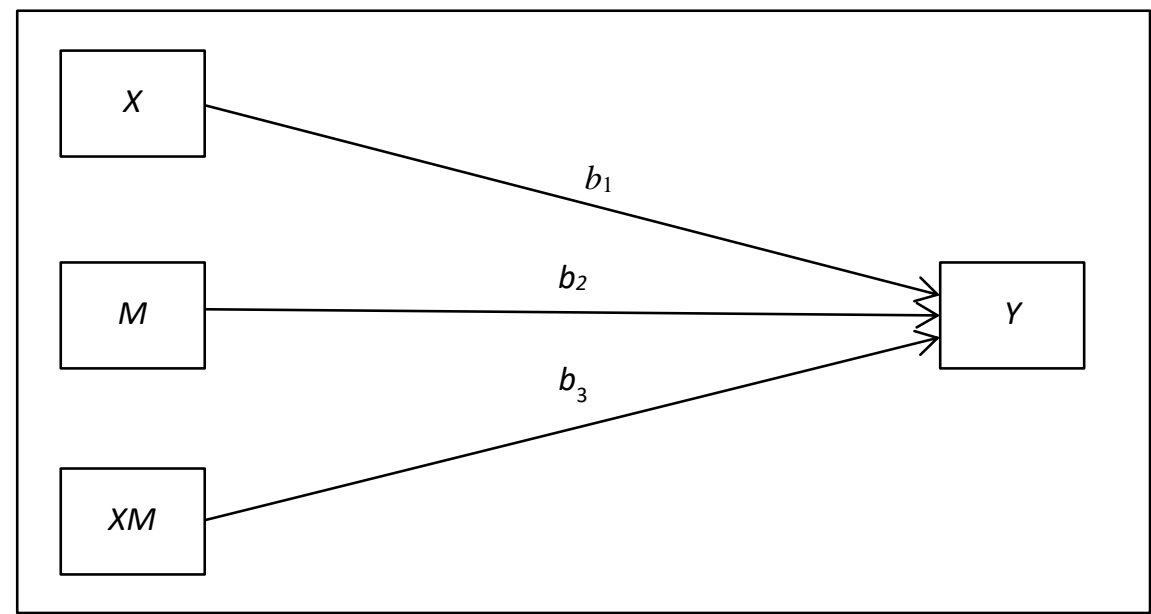

$X^{\prime}$ in Y üzerindeki şartı etkisi $=b_{1}+b_{3} M(X=$ Tüketicilerin fonksiyonel gıdalara karşı güveni, $Y=$ Tüketicilerin fonksiyonel gıdaları satın alma isteği, $M=$ Genel sağlık ilgilenimi) Kaynak: Hayes, 2017 (Model-1)

Şekil 2'de $b_{1}$ ana etkiyi $b_{3}$ ise düzenleyici etkiyi sembolize etmektedir. Buna ek olarak düzenleyici etkinin daha hassas bir şekilde hesaplanabilmesi için $b_{2}$ de araştırma modeline dahil edilmiştir. Çünkü $b_{2}{ }^{\prime}$ nin 
modele dahil edilmemesi durumunda düzenleyici etkinin olduğundan daha abartılı bir biçimde ortaya çıkma riski bulunmaktadır (Hair vd., 2014).

\section{1. Örneklemin Demografik Özellikleri}

Araştırmanın örneklemini oluşturan bireylerin demografik özellikleri Tablo 1'de verilmiştir. Buna göre katılımcıların cinsiyeti kadınlar \%53 ve erkekler \%47 olmak üzere birbirine oldukça yakındır. Katılımcıların \%60'ı evli iken \%55'i çocuk sahibidir. Katılımcılar yaş dağılımları açısından heterojen bir yapı sergilemekle beraber en kalabalık grubu 91 kişi ile 20-29 yaş aralığındaki bireyler oluşturmaktadır. Katılımcıların büyük çoğunluğu ilköğretim ve lise mezunuyken (\%70) diğer eğitim düzeylerine sahip bireyler de örneklemde temsil edilmektedir. Katılımcılar gelir durumları açısından değerlendirildiğinde ise en kalabalık grubu aylık 10012500 TL geliri olan grubun oluştururken, katılımcıların büyük çoğunluğunun gelirinin $(\% 91,7)$ maksimum 4000 TL olduğu görülmektedir.

Tablo 1. Örneklemin Demografik Özellikleri

\begin{tabular}{|c|c|c|c|}
\hline \multirow{2}{*}{ Demografik Unsurlar } & \multirow{2}{*}{ Sınıflandırma } & \multicolumn{2}{|c|}{$n=373$} \\
\hline & & $f$ & $\%$ \\
\hline \multirow{2}{*}{ Cinsiyet } & Erkek & 174 & 46,6 \\
\hline & Kadın & 199 & 53,4 \\
\hline \multirow{2}{*}{ Medeni Hal } & Evli & 225 & 60,3 \\
\hline & Bekar & 148 & 39,7 \\
\hline \multirow{2}{*}{ Çocuk Sahibi Olma } & Evet & 207 & 55,5 \\
\hline & Hayır & 166 & 44,5 \\
\hline \multirow{6}{*}{ Yaş } & $18-19$ & 44 & 11,8 \\
\hline & $20-29$ & 91 & 24,4 \\
\hline & $30-39$ & 64 & 17,2 \\
\hline & $40-49$ & 68 & 18,2 \\
\hline & $50-59$ & 62 & 16,6 \\
\hline & 60 ve üzeri & 44 & 11,8 \\
\hline \multirow{5}{*}{ Eğitim Düzeyi } & ilköğretim & 129 & 34,6 \\
\hline & Lise & 137 & 36,7 \\
\hline & Önlisans & 48 & 12,9 \\
\hline & Lisans & 52 & 13,9 \\
\hline & Lisansüstü & 7 & 1,9 \\
\hline \multirow{5}{*}{ Aylık Gelir (TL) } & 1000 ve altı & 107 & 28,7 \\
\hline & $1001-2500$ & 151 & 40,5 \\
\hline & $2501-4000$ & 84 & 22,5 \\
\hline & $4001-5500$ & 23 & 6,2 \\
\hline & 5501 ve üzeri & 8 & 2,1 \\
\hline
\end{tabular}

\subsection{Geçerlilik ve Güvenilirlik}

Gerçekleştirilen doğrulayııı faktör analizi sonuçlarına göre, ölçüm modeli için ki kare değeri 62 serbestlik derecesinde 174,747 ( $<<0,001)$ ve ki kare/serbestlik derecesi oranı ise 2,819'dur. Bu değer uyum iyiliği açısından kabul edilebilir bir düzeydedir (Carmines ve Mclver, 1981). Diğer uyum indisleri ise sırasıyla RMSEA=0,089; $\mathrm{GFI}=0,900 ; \mathrm{AGFI}=0,887 ; \mathrm{CFI}=0,948$ ve $\mathrm{TLI}=0,935$ olarak gerçekleşmiştir. Bu sonuçlara göre, elde edilen tüm değerler literatürde belirlenmiş olan kabul edilebilir sınırların üzerindedir. Sırasıyla RMSEA ve GFI değerlerinin iyi uyum seviyesinde; AGFI, CFI ve TLI değerlerinin ise kabul edilebilir uyum seviyesinde olduğu görülmektedir (Schermelleh-Engel vd., 2003).

Araştırmada kullanılan ölçekler için güvenilirlik ve geçerliliğin değerlendirilmesi aşamasında literatürde geniş kabul gören iki farklı yöntem benimsenmiştir. Güvenilirlik ve ayrım geçerliliğinin 
değerlendirilmesinde Fornell ve Larcker (1981), benzeşim geçerliliğinin değerlendirilmesinde ise Hair vd. (2011)'in ortaya koymuş oldukları yöntem kullanılmıştır.

Güvenilirliğin değerlendirilmesinde Cronbach's Alpha değerleriyle birlikte AVE ve CR değerlerinden yararlanılmıştır. Buna göre, bir ölçeğin güvenilir olarak değerlendirilebilmesi için, Cronbach's Alpha ve CR değerlerinin $0,70^{\prime}$ ten büyük olması gerekirken, AVE değerinin ise 0,50 'den büyük olması gerekmektedir (Fornell ve Larcker, 1981). Tablo 2'de görülebileceği üzere; tüketici güveni boyutu için Cronbach's Alpha = 0,$89 ;$ CR değeri $=0,89 ;$ AVE değeri ise $0,68^{\prime}$ dir. Sağlık ilgilenimi boyutu için Cronbach's Alpha =0,94; $C R=0,93$ ve AVE değeri ise 0,67 'dir. Her iki boyut içinde Cronbach's Alpha ve CR değerleri $0,70^{\prime}$ in üzerinde ve AVE değerleri de 0,50 'nin üzerinde olduğu için çalışmada kullanılan ölçeklerin güvenilirlik şartını sağladığı söylenebilir.

Tablo 2. Faktör Analizi, Geçerlilik ve Güvenilirliğe iliş̧kin Değerler

\begin{tabular}{|c|c|c|c|c|c|c|}
\hline ifadeler & $\begin{array}{c}\text { Açıklanan } \\
\text { Varyans }\end{array}$ & KMO & $\begin{array}{c}\text { Faktör } \\
\text { Yükü }\end{array}$ & $\begin{array}{c}\text { Cronbach's } \\
\text { alpha }\end{array}$ & $C R$ & $A V E$ \\
\hline & 73,208 & 0,891 & & & & \\
\hline $\begin{array}{l}\text { Fonksiyonel gıdalara yönelik tüketici } \\
\text { güveni }\end{array}$ & 25,409 & & & 0,89 & 0,89 & 0,68 \\
\hline 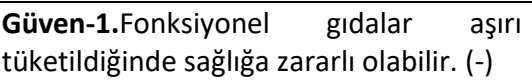 & & & 0,887 & & & \\
\hline $\begin{array}{l}\text { Güven-2.Fonksiyonel gıdalar, bazı } \\
\text { durumlarda, sağılıkı insanlar için zararlı } \\
\text { olabilir. (-) }\end{array}$ & & & 0,892 & & & \\
\hline $\begin{array}{l}\text { Güven-3.Fonksiyonel gıdalar kullanmak } \\
\text { güvenli değildir. (-) }\end{array}$ & & & 0,854 & & & \\
\hline $\begin{array}{l}\text { Güven-4.Fonksiyonel gıdaların } \begin{array}{r}\text { yeni } \\
\text { özellikleri öngörülemeyen riskler } \\
\text { taşımaktadır.(-) }\end{array} \\
\end{array}$ & & & 0,848 & & & \\
\hline Tüketici genel sağlık ilgilenimi & 47,799 & & & 0,94 & 0,93 & 0,67 \\
\hline $\begin{array}{l}\text { Sağlık-1.Yediğim şeylerin sağlıklı olması } \\
\text { konusunda çok seçiciyimdir. }\end{array}$ & & & 0,887 & & & \\
\hline $\begin{array}{l}\text { Sağlık-2.Yiyeceğim şeyin sağlıklı olup } \\
\text { olmadığını düşünmeden, canım ne } \\
\text { isterse onu yerim.(-) }\end{array}$ & & & 0,879 & & & \\
\hline Sağlık-3.Yediğim şeylerin mümkün & & & & & & \\
\hline $\begin{array}{l}\text { olduğunca yağsız olması benim için } \\
\text { önemlidir. }\end{array}$ & & & 0,897 & & & \\
\hline $\begin{array}{l}\text { Sağlık-4.Yediğim şeylerin sağlıklı olup } \\
\text { olmaması bunları tercih etmemi çok az } \\
\text { etkiler.(-) }\end{array}$ & & & 0,803 & & & \\
\hline $\begin{array}{l}\text { Sağlık-5. Her zaman sağıklı ve dengeli } \\
\text { beslenmeye çalışırım. }\end{array}$ & & & 0,842 & & & \\
\hline $\begin{array}{l}\text { Sağlık-6.Günlük yiyeceklerimin vitamin } \\
\text { ve mineral açısından zengin içerikli } \\
\text { olması benim için önemlidir. }\end{array}$ & & & 0,817 & & & \\
\hline $\begin{array}{l}\text { Sağlık-7.Atıştırmalık yiyecekler sağlıksız } \\
\text { olsa da bunları çekinmeden yerim.(-) }\end{array}$ & & & 0,896 & & & \\
\hline $\begin{array}{l}\text { Sağlık-8.Bazı yiyecekleri, kolesterolümü } \\
\text { yükselteceğini bildiğim halde yemekten } \\
\text { kaçınmam.(-) }\end{array}$ & & & 0,823 & & & \\
\hline
\end{tabular}

Bir sonraki aşamada, çalışmada kullanılan ölçekler için benzeşim geçerliliği değerlendirilmiştir. Benzeşim geçerliliğinin sağlanabilmesi için, AVE değerinin 0,50 'den büyük olması ve tüm CR değerlerinin AVE değerlerinden büyük olması gerekmektedir (Hair vd., 2011). Her iki boyut için de AVE değerleri 0,50'den büyük $(0,68$ ve 0,67$)$ ve CR değerleri de AVE değerlerinden büyük olduğu için $(0,89>0,68$ ve $0,93>0,67)$ benzeşim geçerliliğinin sağlandığı söylenebilir. 
Sonraki adımda, ölçekte kullanılan boyutlar için ayrım geçerliliği değerlendirilmiştir. Buna göre her boyut için AVE değeri, gizil değişkenlerin birbirleri ile olan korelasyonlarının karelerinin en büyüğünden daha büyük olmalıdır. Tablo 3'te verilen değerler incelendiğinde bu şartın sağlandığı ve çalışmada kullanılan ölçeklerin ayrım geçerliliğine sahip olduğu görülmektedir.

Tablo 3. Araştırma Modelindeki Gizil Değişkenler İçin Ayrım Geçerliliği

\begin{tabular}{lccc}
\hline & Güven & $\begin{array}{c}\text { Gen. Sağ. } \\
\text { Bil. }\end{array}$ & AVE \\
\hline Güven & 1 & $0,005^{*}$ & $\mathbf{0 , 6 8}$ \\
Gen. Sağ. Bil. & 0,005 & 1 & $\mathbf{0 , 6 7}$ \\
\hline
\end{tabular}

*Gizi değişkenlerin birbirleriyle olan korelasyonlarının kareleri alınarak hesaplanmıştır.

\subsection{Araştırma Hipotezlerinin Testi}

Araştırma kapsamında, tüketicilerin genel sağlık ilgileniminin, fonksiyonel gıdalara yönelik güven ve satın alma isteği arasındaki ilişki üzerinde düzenleyici etkisi olup olmadığını test etmek amacıyla hiyerarşik çoklu regresyon analizi gerçekleştirilmiştir. ${ }^{2}$ ilk aşamada öncelikle tüketici güveni ve genel sağlık ilgilenimi değişkenleri analize dahil edilmiştir. Buna göre tüketici güveni, fonksiyonel gıda satın alma isteğini olumlu yönde etkilemektedir ( $b=-1,23 ; t(228)=-3,41 ; p<0,001)$. Elde edilen bu sonuçla H1 hipotezi doğrulanmıştır.

Araştırmanın diğer bir hipotezinin sonucuna göre, genel sağılık ilgileniminin de fonksiyonel gıda satın alma isteğini olumlu yönde etkilediği görülmüştür ( $b=-0,91 ; t(228)=-3,34 ; p<0,001)$. Bu sonuç H2 hipotezini desteklemektedir. Söz konusu iki değişken, tüketicilerin fonksiyonel gıda ürünü tercihlerindeki değişimin $\% 20$ 'sini anlamlı bir biçimde açıklamaktadır $\left(R^{2}=0,20 ; F(3,228)=18,69 ; p<0,001\right)$.

Sonraki adımda genel sağlık bilinci, güven ve satın alma isteği değişkenleri arasındaki ilişkiye düzenleyici değişken olarak dahil edilmiş ve anlamlı bir etki ortaya çıkmıştır $(b=0,41 ; t(228)=4,62 ; p<0,001)$. Elde edilen bu anlamlı etkinin yanında, düzenleyici değişkenin ilişkiye dahil edilmesi açıklanan varyansı anlamlı̈ ölçüde artırmıştır $\left(F(1,228)=21,32 ; p<0,001 ; \Delta R^{2}=0,075\right)$. Bu sonuca göre genel sağlık ilgileniminin, fonksiyonel gıdalara yönelik güven ve bu gıdaları satın alma isteği arasındaki ilişkide anlamlı bir düzenleyici etkiye sahip olduğu ortaya konmuş ve H3 hipotezi desteklenmiştir.

Hipotez testleri sonucunda elde edilen tüm sonuçlar Tablo 4'te verilmektedir.

Tablo 4. Hipotez Testi Sonuçları

\begin{tabular}{lcccccc}
\hline & b & t & s.d. & p & Sonuç \\
\hline Güven $\longrightarrow$ & Satın alma & $-1,23$ & $-3,41$ & 228 & $* * *$ & H1 Kabul \\
Sağlık ilg. $\longrightarrow$ Satın alma & $-0,91$ & $-3,34$ & 228 & $* * *$ & H2 Kabul \\
Sağlık ilg. (Moderatör) & 0,41 & 4,62 & 228 & $* * *$ & H3 Kabul \\
\hline $\begin{array}{l}\text { s.d. }=\text { Serbestlik Derecesi } \\
* * * \text { p }<0,001\end{array}$ & & & & &
\end{tabular}

Araştırma kapsamında anlamlı bir düzenleyici etki elde edildikten sonra, araştırma hipotezlerine ek olarak, tüketici sağlık ilgileniminin hangi durumlarda daha güçlü bir düzenleyici etkiye sahip olduğu da incelenmiştir. Elde edilen bulgular Şekil 3'te ayrıntılı bir biçimde verilmektedir. Grafik, düzenleyici etki analizi sonucu elde edilen verilerin görselleştirilmiş halidir. Buna göre düşük, orta ve yüksek tüketici güven ve genel sağlık ilgilenimi seviyelerinde fonksiyonel gıda tercihleri aşağıdaki şekilde gerçekleşmektedir. 
Şekil 3. Tüketici Güveni ve Fonksiyonel Gıda Tercihleri Arasındaki Iliş̧ide Genel Sağlık Ilgileniminin Düzenleyici Rolü

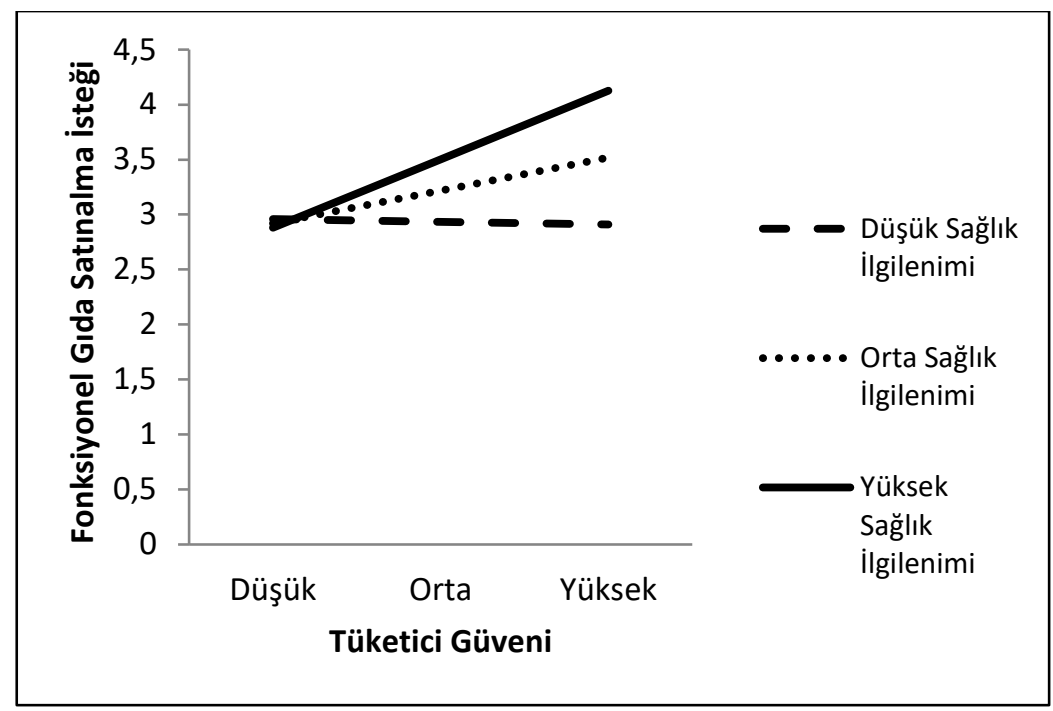

Tüketici sağlık ilgileniminin düşük olduğu durumda fonksiyonel gıdalara yönelik güven düzeyi ne seviyede olursa olsun satın alma isteği düzeyi sabit kalmaktadır. Sağlık ilgilenimi orta düzeyde olan tüketicilerde ise fonksiyonel gıdalara yönelik güven düzeyi yükseldikçe bu ürünleri satın alma istekleri de artmaktadır. Son olarak, sağlık ilgilenimi yüksek düzeyde olan tüketicilerde de fonksiyonel gıdalara yönelik güven arttıkça bu ürünleri satın alma isteklerinin yükseldiği ve bu etkinin orta sağlık ilgilenim düzeyine sahip tüketicilere göre daha da yüksek olduğu görülmektedir.

\section{Sonuç ve Değerlendirme}

Araştırma sonucunda elde edilen bulgulara göre tüketicilerin fonksiyonel gıda tercihlerinde bu gıdalara yönelik güvenin etkili olduğu sonucuna ulaşılmıştır. Bir başka deyişle, tüketicilerin fonksiyonel gıdalara yönelik güven düzeyi arttıkça, bu ürünleri satın alma istekleri de artmaktadır. Bu sonuç literatürdeki bulgularla paralellik göstermektedir (Frewer vd., 2003; Aikman vd., 2006; Ding vd., 2015). Literatürdeki bu çalışmalar güven kavramını, kanun koyuculara yönelik güven ve genel olarak gıda sektörüne yönelik güven gibi farklı boyutlarıyla ele almıştır. Ancak, bir tüketicinin kanun koyuculara ya da genel olarak gıda sektörüne güveni yüksek olup fonksiyonel gıdalara yönelik güveninin düşük bir düzeyde olması teknik olarak mümkündür. Bu bakımdan bu çalışmada güven kavramı spesifik olarak fonksiyonel gıdalara yönelik bir perspektiften ele alındığından, elde edilen bulguların literatüre katkı niteliğinde olduğu söylenebilir. Buna ek olarak, fonksiyonel gıdaların Türkiye pazarında nispeten yeni ürünler olması ve farkındalık düzeylerinin düşük olması (Hacıoğlu ve Kurt, 2012) nedeniyle tüketicilerin bu ürünlerin nitelik ve kaliteleri konusunda yeterli bilgiye sahip olmadıkları bilinmektedir. Bu bağlamda, çeşitli nedenlerden ötürü fonksiyonel gıdalara yönelik bir güven geliştirmiş olan tüketicilerin, bu güveni ürünün nitelik ve kalitesine yordayarak daha fazla tercih ettikleri şeklinde yorumlanabilir.

Çalışmada elde edilen bir diğer sonuç, tüketicilerin sağlık ilgilenimlerinin fonksiyonel gıda tercihlerini pozitif yönlü etkilediği yönündedir. Buna göre tüketicilerin bireysel sağlık ilgilenimleri arttıkça, daha fazla fonksiyonel gıda ürünü tüketme eğiliminde olmaktadırlar. Bu sonuç literatürdeki diğer çalışmaların sonuçlarıyla paralellik gösteren bir niteliktedir (Chen, 2011a; Huang vd., 2019). Güven ve sağlık ilgilenimi değişkenleri, çalışmanın analiz kısmında da belirtildiği üzere, fonksiyonel gıda ürünü tercihlerindeki varyansın yalnızca \%20'sini açıklamaktadır. Literatürde, fonksiyonel gıda tercihlerine etki eden başka unsurların ele alındığı birçok çalışma mevcuttur. Bu çalışmalar fonksiyonel gıda tercihlerinin öncülleri olarak hastalık riskini azaltma (Krystallis vd., 2008); yiyecekte yenilik korkusu (Huang vd., 2019) gibi unsurları ele almaktadır. Buna ek olarak tüketicilerin gıda tercihlerinde, ürünün tadının bu ürünü satın almada en önemli bileşenlerden 
olduğu konusunda ampirik çalışmalar gerçekleştirilmiştir (Aikman vd., 2006) ve bu durumun fonksiyonel gıda ürünü tercihlerinde de geçerli olması beklenebilir. Bu bakımdan açıklanan varyansın bu çalışmada düşük çıkması anlaşılabilir bir durumdur.

Çalışmada ayrıca tüketici güveninin fonksiyonel gıda tercihleri üzerindeki etkisinde, tüketici sağlık ilgileniminin anlamlı bir düzenleyici etkiye sahip olduğu sonucuna ulaşılmıştır. Tüketici güveni ile fonksiyonel gıda tercihleri arasındaki pozitif ilişkiye, sağlık ilgilenimi düzenleyici değişken olarak eklendiğinde, elde edilen etkinin anlamlı ölçüde arttığı görülmüştür. Literatürde bu konudaki bulgular incelendiğinde kültürlerarası anlamda birbirinden farklı sonuçlar elde edildiği görülmüştür. Amerika'da, gıda bilgi konseyi tarafından yapılan bir araştırmada, kendi sağlıklarını mükemmel olarak nitelendiren tüketicilerin fonksiyonel gıdaları daha fazla tükettikleri görülmüştür (IFIC, 2000). Ancak Finlandiya'da gerçekleştirilen başka bir çalışmada ise, fonksiyonel gıdalarla tüketici sağlık ilgilenimi arasındaki ilişkinin oldukça çeşitli olduğu ve bu duruma fonksiyonel gıdaların gerçekten de sağlıklı gıdalar olup olmadıklarına yönelik şüphelerin neden olduğu savunulmaktadır (Niva, 2007). Yine, Ong vd. (2013) Malezya'da gerçekleştirdikleri çalışmada, tüketicinin sağlık durumunun, fonksiyonel gıdalara yönelik tutum ve satın alma davranışı arasındaki ilişkide düzenleyici etkisi olmadığı sonucuna ulaşmışlardır. Kısaca, tüketici sağlık ilgileniminin fonksiyonel gıda tüketimi üzerindeki rolü üzerinde literatürde bir konsensüsün olmadığı görülmekte ve konuyla ilgili olarak gerçekleştirilen çalışmaların sonuçlarının çeşitlilik arz ettiği gözlemlenmektedir. Yine literatüre göre, tüketici sağlık ilgilenimi ve fonksiyonel gıdalara yönelik değerlendirmelerin kültüre göre farklılık gösterdiği söylenebilir. Çalışmada ampirik olarak elde edilen bu sonuç, Türkiye pazarı bağlamında, tüketici sağık ilgileniminin fonksiyonel gıda satın alma davranışlara etkisinin anlaşılmasında literatüre bir katkı niteliğinde olarak değerlendirilebilir.

Çalışmada elde edilen sonuçlar bütünsel bir perspektifle değerlendirildiğinde, Türkiye pazarındaki tüketicilerin fonksiyonel gıda tercihlerinin belirleyicisi olarak güven ve sağlık ilgilenimi kavramları ortaya konmuştur. Bu sonuçlar, özelliklede gıda sektörü oyuncularının Türkiye'de oldukça hızlı büyüyen ve önemli bir potansiyel barındıran fonksiyonel gıda ürünlerine yönelik olarak kurgulayacakları pazarlama stratejilerinin belirlenmesinde belirli bir perspektiften bir kılavuz işlevi görebilir.

Fonksiyonel gıda ürünleri, ürün yaşam eğrisi bağlamında Türkiye pazarında giriş-büyüme dönemindeki ürünler olarak nitelendirilebilir. Bu bakımdan bu ürünlere yönelik tutundurma faaliyetlerinin yakın gelecekte daha da artması beklenebilir. Bu çalışmada elde edilen sonuçlara göre, gıda sektörü oyuncularının fonksiyonel gıda ürünlerine yönelik olarak gerçekleştirecekleri bu tutundurma faaliyetlerinde bu ürünlerin algılanan güvenilirliğini artırmaya yönelik verilecek mesajlar önemli olmakla birlikte tek başına yeterli değildir. Buna ek olarak, pazarı oluşturan tüketicilerin beslenme alışkanlıklarını sağlıklı gıdaları tüketme yönünde teşvik edici mesajlar da verilmeli ve konumlandırma stratejisi bu çerçevede oluşturulmalıdır. Zira bu çalışmada elde edilen sonuçlara göre yüksek sağlık ilgilenim düzeyindeki tüketicilerde, fonksiyonel gıdalara yönelik güvenin satın alma etkisi üzerindeki etkisi en yüksek seviyededir. Fonksiyonel gıda ürünleri için uygun bir hedef pazar ve dar bir pazara hitap edebilecek ölçekteki işletmeler için sağlık ilgilenimi en yüksek olan tüketici grubuna yönelmek oldukça başarılı sonuçlar almalarını sağlayabilir.

Bu araştırmanın bazı sınırlılıkları mevcuttur. Öncelikle araştırma, mevcut imkanlar dahilinde tek bir ilde ve kolayda örnekleme yoluyla gerçekleştirildiğinden, çalışmanın genellenebilir olma niteliğinin yeterli düzeyde olmama riski bulunmaktadır. Diğer bir sınırlıık, araştırmanın yalnızca paketli fonksiyonel gıda ürünleri üzerinde yapılmış olmasıdır. Gelecek çalışmalar fonksiyonel gıdaları daha faklı bir çerçevede ele alınabilir. Bu sayede Türkiye pazarındaki fonksiyonel gıdalarla ilgili daha geniş bir içgörü sağlanması mümkün olabilir. Ayrıca, gelecek çalışmalarda spesifik fonksiyonel gıdaların ele alınması, heterojen bir yapı sergileyen bu ürünlere yönelik daha isabetli bir kavrayış geliştirilmesi bakımından önem arz etmektedir. 


\section{Son Notlar}

1. Fonksiyonel gıdaların gerçekten de sağlıklı gıdalar olup olmadığı konusu çalışma kapsamı dışında bırakılmıştır.

2. Analiz, SPSS programına eklenen Process 2 makrosu kullanılarak gerçekleştirilmiştir. Bkz. (Hayes, 2012).

\section{Kaynaklar}

Aiken, L. S., West, S. G., \& Reno, R. R. (1991). Multiple regression: Testing and interpreting interactions. London: Sage.

Aikman, S. N., Min, K. E., \& Graham, D. (2006). Food attitudes, eating behavior, and the information underlying food attitudes. Appetite, 47(1), 111-114.

Arai, S. (2002). Global view on functional foods: Asian perspectives. British Journal of Nutrition, 88(S2), $139-143$.

Arslan, Y. (2019). Gıda Tüketim trendlerinin şekillenmesinde kanaat önderlerinin rolü: Canan Karatay örneği. Tüketici ve Tüketim Araştırmaları Dergisi, 11(1), 143-176.

Barrios, E. X., Bayarri, S., Carbonell, I., Izquierdo, L., \& Costell, E. (2008). Consumer attitudes and opinions toward functional foods: A focus group study. Journal of Sensory Studies, 23(4), 514-525.

Bleiel, J. (2010). Functional foods from the perspective of the consumer: How to make it a success? International Dairy Journal, 20(4), 303-306.

Brislin, R. W. (1970). Back-translation for cross-cultural research. Journal of Cross-Cultural Psychology, 1(3), $185-216$.

Brom, F. W. (2000). Food, consumer concerns, and trust: Food ethics for a globalizing market. Journal of Agricultural and Environmental Ethics, 12(2), 127-139.

Büyükkaragöz, A., Bas, M., Sağlam, D., \& Cengiz, Ş. E. (2014). Consumers' awareness, acceptance and attitudes towards functional foods in Turkey. International Journal of Consumer Studies, 38(6), 628-635.

Cambridge Commodities, (2017). Functional food market worth €38 billion. http://www.c-c-l.com/news, functionalfood-market-worth-38-billion_718.htm (Erişim Tarihi: 10 Ocak 2019).

Carmines, E., \& Mclver, J. (1981). Analyzing models with unobserved variables. Analysis of covariance structures. In G. W. Bohrnstedt \& E. F. Borgatta (Eds.), Social measurement current issues. Beverly Hills: Sage Publications, Inc.

CDC. (2019). How you can prevent chronic diseases? https://www.cdc.gov/chronicdisease/abo ut/prevent/index.htm (Erişim Tarihi: 10 Ocak 2019).

Chen, M. F. (2011a). The joint moderating effect of health consciousness and healthy lifestyle on consumers' willingness to use functional foods in Taiwan. Appetite, 57(1), 253-262.

Chen, M. F. (2011b). The mediating role of subjective health complaints on willingness to use selected functional foods. Food Quality and Preference, 22(1), 110-118.

Coşkun, R., Altunışık, R., \& Yıldırım, E. (2017). Sosyal bilimlerde araştırma yöntemleri. Adapazarı: Sakarya Kitabevi.

Ding, Y., Veeman, M. M., \& Adamowicz, W. L. (2015). Functional food choices: Impacts of trust and health control beliefs on Canadian consumers' choices of canola oil. Food Policy, 52, 92-98.

Dolgopolova, I., Teuber, R., \& Bruschi, V. (2015). Consumers' perceptions of functional foods: Trust and food-neophobia in a cross-cultural context. International Journal of Consumer Studies, 39(6), 708-715.

Dutra de Barcellos, M., \& Lionello, R. L. (2011). Consumer market for functional foods in South Brazil. International Journal of Food System Dynamics, 2(2), 126-144.

EPCE-European Parliament and Council of Europe, 2006. EC Regulation EC No. 1924/2006 of the European Parliament and of the Council of 20 December 2006 on nutrition and health claims made on foods. Off. J. Eur. Commun. $\mathrm{L}$ 404, L 12/3.

Euromonitor International (2017). Fortified/Functional packaged food market sizes. https://www.euromonitor.com/fortified-functional-packaged-food (Erişim Tarihi: 15 Ocak 2019).

Fandos Herrera, C., \& Flavián Blanco, C. (2011). Consequences of consumer trust in PDO food products: The role of familiarity. Journal of Product \& Brand Management, 20(4), 282-296.

Fornell, C., \& Larcker, D. F. (1981). Evaluating structural equation models with unobservable variables and measurement error. Journal of Marketing Research, 18(1), 39-50.

Frewer, L., Scholderer, J., \& Lambert, N. (2003). Consumer acceptance of functional foods: Issues for the future. British Food Journal, 105 (10), 714-731.

Glaeser, E. L., Laibson, D. I., Scheinkman, J. A., \& Soutter, C. L. (2000). Measuring trust. The Quarterly Journal of Economics, 115(3), 811-846.

Hacıoğlu, G., \& Kurt, G. (2012). Tüketicilerin fonksiyonel gıdalara yönelik farkındalığı, kabulü ve tutumları: İzmir ili örneği. Business \& Economics Research Journal, 3(1), 161-171.

Hair, J. F., Hult, G. T. M., Ringle, C., \& Sarstedt, M. (2014). A primer on partial least squares structural equation modeling (PLS-SEM). Sage Publications. 
Hair, J. F., Ringle, C. M., \& Sarstedt, M. (2011). PLS-SEM: Indeed a silver bullet. Journal of Marketing Theory and Practice, $19(2), 139-152$.

Mellentin, J., \& Heasman, M. (2014). The functional foods revolution: Healthy people, healthy profits. Routledge.

Hayes, A. F. (2012). PROCESS: A versatile computational tool for observed variable mediation, moderation, and conditional process modeling. http://www.afhayes.com/ public/process2012.pdf (Erişim Tarihi: 10 Aralık 2018).

Hayes, A. F. (2017). Introduction to mediation, moderation, and conditional process analysis: A regression-based approach. Guilford Publications.

Hieke, S., \& Grunert, K. G. (2018). Consumers and health claims. In Foods, nutrients and food ingredients with authorised EU health claims, 19-32. Woodhead Publishing.

Hobbs, J. E., \& Goddard, E. (2015). Consumers and trust. Food Policy, 52, 71-74.

Howlett, (2008). Functional foods from science to health and claims. http://ilsi.org/mexico/wpcontent/uploads/sites/29/2016/09/Functional-Foods.pdf (Erişim Tarihi: 11 Ocak 2019)

Huang, L., Bai, L., Zhang, X., \& Gong, S. (2019). Re-understanding the antecedents of functional foods purchase: Mediating effect of purchase attitude and moderating effect of food neophobia. Food Quality and Preference, 73, 266-275.

Hutt, A., (2016). What is a functional food? https://www.ift.org/career-development/learn-about-food-science/foodfacts/what-is-a-functional-food (Erişim Tarihi: 25 Aralık 2018).

IFIC. (2000). Functional foods. Attitudinal research. International Food Information Council Foundation, Washington, USA.

Lockie, S., Lyons, K., Lawrence, G., \& Mummery, K. (2002). Eating green: Motivations behind organic food consumption in Australia. Sociologia Ruralis, 42, 23-40.

Luhmann, N. (2000). Familiarity, confidence, trust: Problems and alternatives. In Trust: Making and breaking cooperative relations (ed. by D. Gambetta), pp. 94-107.

Kaur, N., \& Singh, D. P. (2017). Deciphering the consumer behaviour facets of functional foods: A literature review. Appetite, 112, 167-187.

Krystallis, A., Maglaras, G., \& Mamalis, S. (2008). Motivations and cognitive structures of consumers in their purchasing of functional foods. Food Quality and Preference, 19(6), 525-538.

Niva, M. (2007). All foods affect health: understandings of functional foods and healthy eating among health-oriented Finns. Appetite, 48(3), 384-393.

Ong, F. S., Kassim, N. M., Peng, O. S., \& Singh, T. (2014). Purchase behaviour of consumers of functional foods in Malaysia: An analysis of selected demographic variables, attitude and health status. Asia Pacific Management Review, 19(1), 81-98.

Popkin, B. M. (1999). Urbanization, lifestyle changes and the nutrition transition. World Development, 27(11), 19051916.

Remarcle, C., \& Reusens, B. (2004). Functional foods ageing and degenerative disease. Woodhead Publishing Limited.

Roininen, K., Lähteenmäki, L., \& Tuorila, H. (1999). Quantification of consumer attitudes to health and hedonic characteristics of foods. Appetite, 33(1), 71-88.

Schermelleh-Engel, K., \& Moosbrugger, H. (2003). Evaluating the fit of structural equation models: Tests of significance and descriptive goodness-of-fit measures. Methods of Psychological Research Online, 8(2), 23-74.

Schifferstein, H. N. J., \& Oude Ophuis, P. A. M. (1998). Health-related determinants of organic foods consumption in the Netherlands. Food Quality and Preference, 9(3), 119-133.

Sekaran, U., \& Bougie, R. (2016). Research methods for business: A skill building approach. John Wiley \& Sons.

Siegrist, M., Stampfli, N., \& Kastenholz, H. (2008). Consumers' willingness to buy functional foods. The influence of carrier, benefit and trust. Appetite, 51(3), 526-529.

TUiK (2019). Nüfus istatistikleri. http://www.tuik.gov.tr/UstMenu.do?metod=temelist (Erişim Tarihi: 15 Aralık 2018).

Urala, N., \& Lähteenmäki, L. (2007). Consumers' changing attitudes towards functional foods. Food Quality and Preference, 18(1), 1-12.

Verbeke, W. (2006). Functional foods: Consumer willingness to compromise on taste for health? Food Quality and Preference, 17(1-2), 126-131.

Williams, P. (2005). Consumer understanding and use of health claims for foods. Nutrition Reviews, 63(7), $256-264$.

World Health Organization (2003). Diet, nutrition and the prevention of chronic diseases. World Health Organization Technical Report Series, 916, 1-8.

World Health Organization (2014). Global status report on noncommunicable diseases, https://www.who.int/nmh/publications/ncd-status-report-2014/en/ (Erişim Tarihi: 16 Ocak 2019). 
This Page Intentionally Left Blank 